\title{
TERMITE DAMAGE AND CONTROL AS FACTORS IN THE UTILIZATION OF TIMBER IN THE CARIBBEAN AREA ${ }^{1}$
}

\author{
George N. Wolcott ${ }^{2}$ \\ INTRODUंCTION
}

Dry-wood termites, depreciation, hurricanes, and fire are the modern Four Horsemen of the Apocalypse: the four most destructive agents of wooden structures in the West Indies. This is most amusingly illustrated by a poster of the Ponce Cement Co. of Puerto Rico, showing Ponce de León with sword and cement as "protector of the home." That two cement plants are in capacity operation in Puerto Rico, and that every other major island earnestly wishes it was even half as well provided, is only one indication of how largely wood has been supplanted for construction in the last few years.

Wooden furniture is still generally used in concrete houses, however, although steel, glass, and plastic are constantly finding greater acceptance. The use of concrete for furniture is still limited to outdoor benches built by fanatics who have lost too many treasured relics from termite attack. Despite their initial high cost, permanent concrete fence posts are cheaper in the end than those of any kind of available wood, unless the stakes are living and are expected to form a hedge. Such stakes must take root promptly or be destroyed by termites or other insects, and even when wellrooted and firmly established, are always subject to termite attack. Telephone poles unprotected by heavy creosote impregnation may be noted in the Dominican Republic so completely eaten by termites that the crossarms bearing the termite nest are supported by the wires from the adjacent poles.

The obverse aspect of the increasing displacement of wood in the West Indies is that desirable woods are becoming so much more valuable that their production should be definitely profitable on a long-term basis. The mahogany shade trees lining the streets of Paramaribo, Dutch Guiana, are not only an invaluable asset now, but when and if they have to be removed will have acquired an enormous commercial value. Large areas in Hispaniola, abandoned as cane fields, might well be planted to mahogany as a long-term investment, eventually yielding a greater financial return than all the crops of sugarcane that had been grown on them. The extensive

1 From a paper presented at a Caribbean Commission Conference on Caribbean Timbers, Their Utilization and Trade Within the Area, Port-of-Spain, Trinidad, B.W.I., Apr.'13-18, 1953.

2 Entomologist and Head of Department, Agricultural Experiment Station, University of Puerto Rico, Río Piedras, P. R. 
planting of East Indian teak in Trinidad might well be extended to include not only endemic trees but also other species from the Guianas and the Amazon Basin definitely known to be very resistant to dry-wood termite attack. The possibilities seem limitless, as compared to present accomplishments, but could readily be made practical actualities based on data already available.

\section{BIOLOGY OF THREE VARIETIES OF TERMITES}

In addition to the endemic species of termites present in the various West Indian islands, unfortunate introductions in commerce from fardistant realms of the British Empire have created special problems in some of the British West Indies, but even including these, the economically important termites fall into three groups: Nigger-head nest termites, subterranean termites, and dry-wood termites.

\section{Nigger-head Nest Termites}

The common and typical nigger-head nest species is Nasutitermes costalis Holmgren, characterized by broad and easily broken external tunnels originally extending from the nest in the ground up the trunks of trees to dead branches, and eventually from the characteristic aerial "nigger-head" nest of the later development of the colony down to the ground. These termites require subterranean sources of water in addition to that obtained from the wood of dead branches, and eventually perish if cut off from connection with the ground. Because their conspicuous nests are so easily destroyed either mechanically or by poisoning with paris green during dry weather, they are normally rural inhabitants, finding continued existence in cities practically impossible. In the country, however, they are so omnipresent as to be the principal agents in the destruction of fence posts and wooden structures in general, if not closely watched.

Several yards of their lightly constructed tunnel may be extended overnight to a new source of food discovered by nocturnal foragers, not even overlooking so small an item as an empty wooden matchbox. The danger of being hit by a falling branch during a storm in the Tropics is much less because these termites promptly consume all branches as soon as they die, leaving little more than the bark and their fragile tunnels to be blown by the wind. Indeed, it is with the greatest difficulty that one can collect enough dry firewood of dead branches to make and keep a sizable fire going in a tropical forest. Any kind of wood is subject to attack, Luis F. Martorell of this Station having recorded 84 kinds of trees attacked in Puerto Rico, not excluding live mahogany trees as nest sites, although only dead branches were eaten.

But these termites much prefer some kinds of trees, the flamboyán being almost invariably infested. As flamboyán trees are so often used for road- 
side planting, at times the "camineros" in Puerto Rico assigned to keep roads in repair have attempted to eliminate the unsightly nests from the trees within their jurisdiction. Such successful campaigns are of very temporary value, however, for reinfestation from surrounding areas inevitably occurs with the swarming of adults the following spring.

People living in the country find the swarming adults very much of a nuisance in the late spring, for they are readily attracted to artificial lights. This practically necessitates finishing dinner before.dark if one is to avoid having the black-winged, clumsy adults perish in the soup. Despite all this, Nasutitermes is really a very minor pest economically, and even incipient colonies, which have not yet developed aerial nests, may be eliminated by placing dry paris green in the largest tunnels, or by spraying the tunnels and soaking the ground beneath with one of the new chlorinated hydrocarbon insecticides such as Chlordan or Aldrin.

\section{Subterranean Termites}

Subterranean termites, of which Heterotermes tenuis Hagen is the typical species of the West Indies, construct no aerial nest, and their tunnels are small; tough, and so difficult to: eliminate completely that a black streak remains after the most strenuous efforts at destruction. They are primarily city dwellers, but may occur anywhere, and seem to be increasing in numbers as well as in the areas of infestation. With no visible nest, they are exceptionally difficult to combat, their tunnels being so small that only the smallest amounts of poison can be inserted and this proves quite insufficient to eliminate a colony. Destruction of the external tunnels is only a palliative at best, for they may be repaired overnight. Not easily discouraged, these termites will rebuild tunnels through earth impregnated with 10-percent DDT in crankcase oil and over concrete foundations similarly sprayed, up to the top story of wooden buildings, and extend their tunnels downward like stalactites from molding or ceiling.

For old buildings, not constructed with reference to possible subterranean termite infestation, and especially for those with wooden members extending through the concrete floor or foundation and in direct contact with the soil, only the most strenuous and thorough soil treatment offers any chance of success. Luck is as important a factor as any, for the principal nest may be yards distant from the foundation or it may be directly under the building. Many new chemicals have become commercially available within the past few years, some of which initially gave remarkably good results, but none has been tested long enough to prove its permanence in termite control. One can only mention Aldrin and Dieldrin as being apparently the most effective and hope that future results will prove that this prognostication is correct. The other possibility with old buildings is to make struc- 
tural changes, eliminating the wooden members in contact with the soil, or the cracks and breaks in the concrete foundation through which the termites gain access to the interior. If the old building has a wooden floor, either this must be eliminated, or the soil underneath, and outside as well, should be treated.

There is little hope for old wooden buildings attacked by subterranean termites, but when they are eliminated, replacement in an area known to be infested should be made only after the soil has been treated with Aldrin. New structures should be of concrete, or on concrete or masonry foundations raising the floor high enough above the ground so that it is readily accessible beneath for suitable control measures to be taken if necessary.

Perfection counsels that structures, to be termiteproof to subterranean termites and nigger-head nest termites, should be built like a boat, with no cracks or apertures through which either water or termites can find ready means of access from beneath.

Insufficient observations have been made on the food preferences of subterranean termites in the Tropics to make possible definite statements. Most of the injuries reported have been to books and cotton clothing, and to the sapwood of southern pine, leaving mahogany and similar tropical hardwoods untouched, or with tunnels passing over them as though they were completely unedible.

\section{Dry-wood Termites}

The fundamental difference between the West Indian dry-wood termite, Cryptotermes brevis Walker, and other termites is that the dry-wood species obtain all the moisture required during their entire life from dry wood. At no period of their existence do they live in the ground, and they require no connection with it, thus protection from their depredations in no way depends upon how a structure is constructed or on its foundations. The drywood termite can live indefinitely in a picture-frame on a wall, suffering no privation of anything essential to its well-being until the picture-frame collapses. No practical method of screening, adequate against mosquitoes and houseflies, will keep these termites out, and indeed most screened houses seem to be more heavily infested because of a mistaken idea that they had been thereby protected against termite attack. Wooden members of a concrete house are just as readily attacked as are wooden houses, and furniture is just as subject to infestation one place as another.

\section{TERMITE-RESISTANT WOODS}

The situation is by no means hopeless, however, for numerous tropical woods are practically or entirely immune from attack, and any wood whatsoever may be rendered externally repellent by painting all surfaces, or 
complete submergence in suitable chemicals. Only the exceptional furniture manufacturer is interested in the permanence of his product abroad, and if the bulk of it is for use where termites do not exist, treatment of susceptible woods so that tropical termites will not eat them seems quite unessential. The first cost of furniture made abroad may be less, but ultimately it will prove to be much more expensive than that made locally of woods proved by experience to be termite-resistant.

To make adequate supplies of such woods commercially available should be the aim of the forester, for the high cost of locally made furniture is largely due to the scarcity of supply of the most desirable woods. Termiteresistance of a wood would appear to have no survival value to any species of tree, but nevertheless, practically all the termite-resistant woods are from tropical trees. The gummy heartwood of the bald cypress of the southern United States, Taxodium distichum (L.) Rich., cannot be eaten by drywood termites, but is rarely available in commercial quantities at present. Osage-orange, Maclura pomifera (Raf.) Schneider, a hedge and fence-post tree extensively planted by the first settlers in the middle western United States before barbed wire had been invented, and previously used by the Indians for making bows, rarely attains a size suitable for extensive commercial use, and only recently has its exceptional characteristic of being termite-resistant been proved. Most of the other Temperate Zone trees tested are very susceptible to termite attack, and all of the remainder are susceptible.

Any one of these woods, if adequately treated with suitable chemicals either before or after being made into furniture, can be rendered immune to termites, but proof of a treatment depends upon the integrity of the manufacturer, or failing that, on the persistence and industry of the individual purchaser before infestation occurs. Actually, very few persons are psychologically prepared, or have the time and inclination to treat their furniture with adequate thoroughness at the time of purchase, or to supervise the building of a house to make sure that the cut end of each piece of wood entering into its construction is treated before being nailed into place. It should be emphasized that nothing less will give complete protection against dry-wood termites, and you may be sure that, eventually, they will discover any area carelessly left untreated. Except for plywood to which the repellent is applied in the process of manufacture, penetration by any chemical is so shallow that the interior is protected only by the thin outer layer of wood, and if this is penetrated, the entire interior is susceptible to attack. Thus, until more adequate methods of depth penetration are universally adopted for lumber and furniture imported into the Tropics, endemic termite-resistant woods have a practical monopoly.

Experience over generations of life in the Tropics has accumulated a 


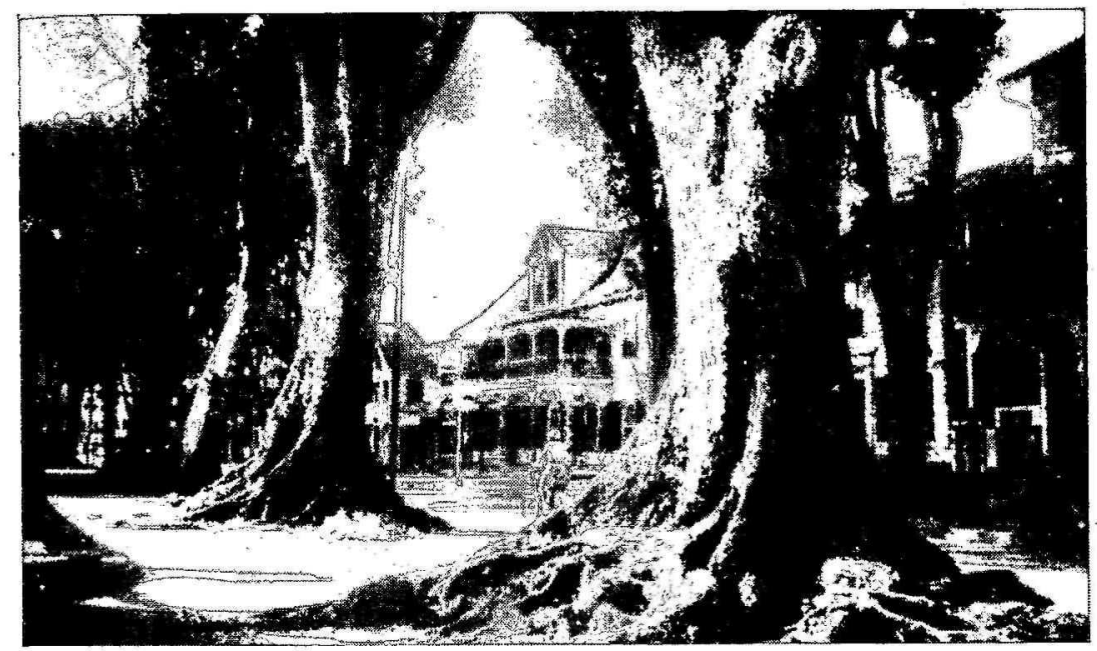

Fig. 1.-Street of Paramaribo, Dutch Guiana, lined with trees of West Indian mahogany. (Original).

mass of more or less correct opinions regarding the termite-resistance of endemic woods. This is so overwhelmingly consistent in the case of mahogany that the promoters of other kinds of woods with somewhat similar physical properties and appearance have adopted this name for woods that are chemically and fundamentally different, and have little of the termiteresistance of genuine West Indian mahogany, Swietenia mahagoni Jacquin (see fig. 1). Such woods may serve reasonably well in countries where drywood termites do not exist, but in the Tropics their use will eventually result in bitter disappointment to the innocent purchaser of an article made of Philippine mahogany, African mahogany, Dutch mahogany, or even Honduras mahogany. The termites unerringly recognize the fraud, and move in for its destruction.

Adequate chemical treatment would permanently prevent termite attack on thin plywood sheets. Such practices have been used to make permanently termite-resistant abundant supplies of termite-susceptible woods such as okoumé, birch, makore, and lauan, which thus treated are suitable for use in the Tropics. In all of these woocis, the chemical use is the commercially available pentachlorphenol or sodium pentachlorphenate. Thus, the end result is complete substitution for mahogany, but this alternative is not on that account to be dismissed as unworthy of serious consideration for general adoption.

West Indian mahogany is not the only wood which the consensus of opinion regards as notably resistant, but concerning so many other's no 
general agreement had been reached that one of the historic problems for investigation by the entomologist has been to make comparative tests.

The first report on "The Comparative Resistance of Woods to the Attack of the Termite, Cryptotermes brevis Walker" was made in $1924(1)^{3}$ and was followed by another in 1946 (2). Such tests are still in progress, the latest publication: "An Index to the Termite-Resistance of Woods" (3) from the Station, being already somewhat out of date.

Such tests, especially for the more valuable, termite-resistant woods, necessitate the expenditure of enormous numbers of termites in making the comparison with other similar termite-resistant woods, and require very long periods of time for completion. Susceptible woods, readily eaten by termites and causing .little or no mortality of the experimental animals, take but comparatively little time before they can be rather definitely placed in their relation to other susceptible woods of little or no commercial value as cabinet or construction woods, unless chemically treated for termite-resistance. With so much data available, it is now within the province of the forester to advise and suggest for planting those trees of the greatest commercial value because of the termite-resistance of their wood, rather than those which merely grow rapidly and produce the most immediate results. The farmer is not concerned with the esthetic value of the luxuriant growth of weeds, and a similar, realistic attitude towards the crop which he is recommending should be adopted by the forester.

\section{SUMMARY}

The destructiveness of termites presents a challenge to everyone connected with forestry and wood utilization in the Tropics, as well as to the consuming public. On the basis of biological differences and methods of control, the West Indian species divide into three groups: The "niggerhead" nest termites, of which Nasutitermes costalis Holmgren is typical and most common, but commercially least injurious; the subterranean termites, of which Heterotermes tenuis Hagen is most destructive; and the dry-wood termite, Cryptotermes brevis Walker.

Some of the new insecticides, more especially those developed by Julius Hyman, such as Chlordan, Aldrin, Dieldrin, and others, are exceptionally effective in killing termites, and the impregnation of susceptible woods with pentachlorphenol or sodium pentachlorphenate prevents attack so long as this thin surface protection is unbroken. But as all North American woods except the gummy heartwood of bald cypress and Osage orange are susceptible to termite attack, the foresters of the Caribbean area have a unique opportunity in pushing the commercial planting of endemic termite-

${ }^{3}$ Numbers in parentheses refer to Literature Cited, p. 122. 
resistant woods such as West Indian mahogany, Demerara greenheart, and others less well-known, as well as East Indian teak.

\section{RESUMEN}

Este trabajo presenta datos relacionados con la biología y el poder destructivo del comején, Nasutitermes costalis Holmgren; del comején subterráneo, Heterotermes tenuis Hagen; y de la polilla de la madera seca de las Indias Occidentales, Cryptotermes brevis Walker. Mientras la primera, relativemante es una plaga de menor importancia económica, las otras dos son marcadamente destructivas en todas las edificaciones y objetos construídos con madera.

Se discuten los métodos de control, y también se recomiendan con especial énfasis, el método científico de poner los edificios a prueba de estas polillas, y el tratamiento que se les debe dar a las maderas que se usen en la fabricación de muebles para que resistan los ataques de estos insectos.

Se sugiere, como medida rutinaria y conveniente en los trópicos, la siembra extensiva de árboles cuya madera resista la polilla.

\section{LITERATURE CITED}

1. Insular Station Bulletin No. 33, p. 15, San Juan, P. R., 1924.

2. Caribbean Forester, October 1946.

3. Bulletin No. 85, Agricultural Experiment Station, University of Puerto Rico, R.jo Piedras, P. R., pp. 26, 1950. 